\title{
Quantification and Evaluation of Antioxidant Activity of Some Bioactive Phytochemicals in Different Medicinal Plants
}

\author{
P. Singh ${ }^{1}$, S.P. Vishwakarma ${ }^{1}$, U. Singh ${ }^{1}$, M. Shukla ${ }^{1}$, R. Singh $^{2}$, R.K. Singh $^{3}$, R.B. Singh ${ }^{4}$, Douglas \\ W. Wilson ${ }^{5}$ and R.L. Singh ${ }^{1, *}$
}

${ }^{1}$ Nutraceutical Laboratory, Department of Biochemistry, Dr. RML Avadh University, Faizabad-224001, India

${ }^{2}$ Biochemistry Department, C S M Medical University, Lucknow-226003, India

${ }^{3}$ Biochemistry Department, SGRRIM\&HS, Patel Nagar, Dehradun-248001, India

${ }^{4}$ Halberg Hospital and Research Institute, Moradabad, India

${ }^{5}$ School of Medicine and Health, Durham University, UK

\begin{abstract}
The present study was carried out to determine the concentration of some bioactive phytochemicals (ascorbic acid, carotenoids, total phenolics, protein and carbohydrate) and their antioxidant activity in the some medicinal plants. To screen out the plants, as well as their parts having higher antioxidant activities, all main parts of plants were screened. Out of thirteen plant samples, ethanolic leaf extract of $T$. belerica showed minimum $\mathrm{IC}_{50}$ for free radical scavenging capacity $(0.08 \mathrm{mg} / \mathrm{ml})$, superoxide anion radical scavenging activity $(0.39 \mathrm{mg} / \mathrm{ml})$, lipid peroxidation $(0.31 \mathrm{mg} / \mathrm{ml})$ and ferric thiocyanate chelation activity $(0.89 \mathrm{mg} / \mathrm{ml})$ as well as high reducing power $(0.31 \mathrm{ASE} / \mathrm{ml})$ capacity. We can infer that the parts of plant having high content of phytochemicals may serve as a good source of nutraceuticals which have potential for use in health care formulations.
\end{abstract}

Keywords: Phytochemicals, Nutraceuticals, Antioxidant, Phenolics, Ascorbic acid, Healthcare.

\section{INTRODUCTION}

There are several medicinal plants which are known to support immune function and provide resistance against infection caused by microorganisms as well as in the prevention of diseases caused by overproduced free radicals. Experimental evidence suggests that free radicals (FRs) and reactive oxygen species (ROS) may be involved in a number of diseases. Antioxidants (endogenous as well as exogenous) may, for example, donate one of its electrons to the free radicals to make them stable molecules. If no antioxidants are present, the free radicals take an electron from vital cell structures, damaging the cells leading to several chronic diseases. This requirement is fulfilled by the supplementation of phytochemical rich diets. Medicinal plants containing phytochemicals with antioxidant potential have strong protective effect against major diseases including cancer, diabetes, hepatotoxicity, Alzheimer's Disease, cataract and other cardiovascular diseases [1]. It has been reported that the diets rich in vegetables, fruits and medicinal plants provide a wide range of antioxidant phytochemicals such as polyphenolics, carotenoids, terpenoids, flavonoids, vitamins like $\mathrm{E}$ and $\mathrm{C}$, glutathione and vegetable pigments. These phytochemicals offer protection against cellular damage due to their ability to

*Address correspondence to this author at the Department of Biochemistry, Dr. R.M.L. Avadh University, Faizabad - 224 001, U.P., India;

Tel: +91 94157 16591; Fax: +91 5278 246330;

E-mail: drrlsingh@rediffmail.com quench oxygen-derived free radicals by donating electrons, chelating redox active metals and by inhibiting lipooxygenases [2]. It has been suggested that there is an inverse relationship between dietary intake of antioxidant rich foods and the incidence of diseases. Phenolic compounds have the potential to function as antioxidants by scavenging the superoxide anion, hydroxyl radical, peroxy radical or quenching singlet oxygen and by inhibiting lipid peroxidation in biological systems [3]. Oxidative stress, which results due to imbalance between the antioxidant defence system and the formation of ROS, may induce damage to cellular biomolecules such as DNA, RNA, proteins, enzymes, carbohydrates, and lipids through oxidative modification and contributing to the pathogenesis of human diseases [4]. One of the earliest literatures of Indian medicine, the 'Charaka Samhita' (1000 B.C.), mentions the use of over 2000 herbs for medicinal purpose. According to a WHO survey, $80 \%$ of the population living in the developing countries are now showing faith in traditional medicine for their primary health care needs. It is well known that the available synthetic drugs may not be able to completely cure the fatal diseases. It is already known that some treatments for these diseases produce side effects. So there is a need to find out other more safer alternatives for the treatment of certain diseases. In view of increasing awareness towards health and increased use of phytochemicals in the prevention and treatment of common as well as serious diseases, there is a need to explore the possibilities of including phytochemicals as well as 
health care products in our daily diet. In the present study, medicinal plants have been screened and different parts of the plants have been evaluated for their antioxidant potential.

\section{MATERIALS AND METHODS}

\subsection{Materials}

Plant materials collected from different natural habitats from districts of Uttar Pradesh (Lucknow, Faizabad), were chopped, dried, powdered and stored in polythene bags at $4^{\circ} \mathrm{C}$ till further analysis. Identification of different plant samples was carried out and confirmed with the help of National Botanical Research Institute (NBRI), Lucknow, India. The voucher specimens were also deposited at NBRI for reference.

\subsection{Chemicals and Reagents}

Gallic acid, quercetin and bovine serum albumin (BSA) were procured from Sigma-Aldrich, St. Louis, USA. $\beta$ Carotene, Ascorbic acid, Folin Ciocalteau's phenol reagents were the product of E. Merk, Mumbai, India. Nitro blue tetrazolium (NBT), 1,1-diphenyl-2-picrylhydrazyl (DPPH), thiobarbituric acid (TBA), phenazine methosulphate (PMS), reduced nicotinamide adenine dinucleotide (NADH), potassium ferricyanide, trichloroacetic acid, ferric chloride and sodium dodecyl sulphate were purchased from SRL India. All other reagents and chemicals used were of analytical grade.

\subsection{Estimation of Phytochemicals}

Ascorbic acid content of plants was estimated by the method of Arlington [5], and reported as $\mathrm{mg}^{100 \mathrm{~g}^{-1}}$ fresh weight (FW) ) of tissues. Carotenoids were estimated by the method of Jensen [6] and reported as $\mu \mathrm{g} \mathrm{g}^{-1} \mathrm{FW}$. Total phenolic content (TPC) was measured using the method of Ragazzi \& Veronese [7] and reported in terms of $\mathrm{mg}$ of gallic acid equivalent (GAE) $\mathrm{g}^{-1}$ of dry weight (DW). Protein content was estimated by the method of Lowry et al. [8] and reported as $\mathrm{mg} \mathrm{g}^{-1}$ of DW. Carbohydrate content was estimated by Anthrone method [9] and reported as $\mathrm{mg} \mathrm{g}^{-1}$ of DW.

\subsection{Extraction Procedure for Antioxidant Assay}

Twenty gram of dried and powdered plant samples were extracted with $70 \%$ ethanolic solvent until decoloration. The extracted solvent was evaporated at $40^{\circ} \mathrm{C}$ in a vacuum rotary evaporator and lyophilized till dryness. The powdered form of plant extract was stored at $-4^{0} \mathrm{C}$ and used for the antioxidant activity determination.

\subsection{Antioxidant Studies}

Free radical scavenging activity (FRSA) was measured using DPPH solution, according to Yen and Duh [10] and expressed in the terms of inhibitory concentration $\left(\mathrm{IC}_{50}\right)$, efficiency concentration $\left(\mathrm{EC}_{50}\right)$ and anti radical power (ARP). Superoxide anion radical scavenging activities were examined by the method of Nishikimi et al. [11]. Reducing power (RP) was determined by ferric reducing antioxidant power assay, and expressed as ascorbic acid equivalents (ASE) per Millilitre sample [12]. The ASE value is inversely proportional to reducing power $(1 \mathrm{mM}$ ascorbic acid $=1$ ASE). Lipid peroxidation (LPO) was determined using egg homogenate as lipid rich source according to Ohkawa et al. [13]. Ferric thiocyanate assay was performed according to Tsuda et al. [14] and results were expressed in terms of inhibitory concentration $\left(\mathrm{IC}_{50}\right)$.

\subsection{Statistical Analysis}

Values from in vitro antioxidant activities shown in figures and table were the mean \pm standard deviation (SD) of at least three independent determinations. Correlation analyses of antioxidant activity (y) versus the total phenolic content (X) were carried out using the correlation and regression programme in MINITAB 13.2 (Minitab 2002 Software Inc., Pennsylvania, PA).

\section{RESULTS AND DISCUSSION}

\subsection{Estimation of Phytochemicals}

In order to find out the higher concentration of phytochemicals in the plants which impart antioxidant activity, eight plants were examined for their ascorbic acid, carotenoids, total phenolics, protein and carbohydrate contents (Table 1). The results indicated that the concentration of

Table 1. Tested Medicinal Plants with their Botanical Name

\begin{tabular}{|c|c|c|c|}
\hline S.No. & Botanical Name & Common Name & Family \\
\hline \hline 1. & Andrographis peniculata (AP) & Kalmegh & Acanthaceae \\
\hline 2. & Aleo vera (AV) & Grithkumari & Liliaceae \\
\hline 3. & Musa paradisca (MP) & Banana & Euphorbiaceae \\
\hline 4. & Phyllanthus amarus (PA) & Gangali amla & Nyctaginaceae \\
\hline 5. & Boehaavia diffusa (BD) & Punarnava & Combretaceae \\
\hline 6. & Terminalia belerica (TB) & Bahenda & Zingiberaceae \\
\hline 7. & Curcuma longa (CL) & Turmaric & Asteraceae \\
\hline 8. & Eclipta prostrata (EP) & Bhringaraj & \\
\hline
\end{tabular}


phytochemicals varied among plant genotypes as well as among different organs of the same plant due to the effect of different factors such as light, temperature, soil, location, and climatic as well as seasonal variations.

\subsubsection{Ascorbic Acid}

Medicinal plants that were tested showed varying level of ascorbic acid ranging from 10.20 to $118.36 \mathrm{mg} 100 \mathrm{~g}^{-1} \mathrm{FW}$ (Table 2). Based on this wide variation in the ascorbic acid content, plant samples were divided into three groups namely high $(>100 \mathrm{mg})$, medium $(30-100 \mathrm{mg})$ and low $(<30$ $\mathrm{mg}$ ) ascorbic acid/100g of FW. Among the plant samples, the highest value of ascorbic acid was present in Phyllanthus amarus (PA) leaves (118.36 mg/100g of FW) making them a good source of ascorbic acid whereas lowest concentration of ascorbic acid was present in Musa paradisca unripe fruit pulp $(10.20 \mathrm{mg} / 100 \mathrm{~g}$ of FW). The moderate levels of ascorbic acid were present in Andrographis peniculata (AP), Musa paradisca (MP) and Eclipta prostrata (EP) leaves. The fundamental role of ascorbic acid is to react non- enzymatically with superoxide, hydrogen peroxide, singlet oxygen etc. to minimize the damage caused by oxidative stress. Stephan [15] showed that the ascorbic acid has the ability to enhance the body's antioxidant defence and is important in the healing of ulcers and delays the onset of other diseases. Cioroi [16] reported that ascorbic acid acts as antioxidant and the role of ascorbic acid is to neutralize free radicals. A favorable amount of ascorbic acid is present in $P$. amarus leaf showing its potential utility as nutraceuticals.

\subsubsection{Carotenoids}

Carotenoids are powerful antioxidants which help to scavenge free radicals and provide support to the body's immune system against infections. Carotenoid content of the tested plants have been shown in Table 2. A wide variation in carotenoids concentration was observed ranging from 0.47 $\mu \mathrm{g} / \mathrm{g}$ to $20.26 \mu \mathrm{g} / \mathrm{g}$ of FW. Results showed that among the tested plant parts, E. prostrata leaf had the highest concentration of carotenoids i.e. $20.26 \mu \mathrm{g} / \mathrm{g}$ of $\mathrm{FW}$ whereas the lowest concentration of carotenoids was noticed in Curcuma

Table 2. Ascorbic Acid, Carotenoids Content in Different Tested Medicinal Plants

\begin{tabular}{|c|c|c|c|c|}
\hline S.No. & Plant sample & Plant parts & Ascorbic acid (mg/100g of $\left.{ }^{\mathbf{1}} \mathrm{FW}\right)$ & Carotenoid ( $\mu \mathrm{g} / \mathrm{g}$ of $\left.{ }^{1} \mathrm{FW}\right)$ \\
\hline 1. & A. peniculata & Leaf & $42.17 \pm 2.36$ & $12.39 \pm 0.66$ \\
\hline 2. & A. vera & Leaf & $23.86 \pm 2.21$ & $2.70 \pm 0.16$ \\
\hline \multirow[t]{5}{*}{3.} & \multirow[t]{5}{*}{ M. paradisca } & Leaf & $69.38 \pm 4.08$ & $1.27 \pm 0.30$ \\
\hline & & Fruit $\left({ }^{2} U R\right)$ pulp & $10.20 \pm 1.77$ & $1.51 \pm 0.05$ \\
\hline & & Fruit $\left({ }^{3} \mathrm{R}\right)$ pulp & $16.32 \pm 1.77$ & $1.17 \pm 0.16$ \\
\hline & & Fruit $\left({ }^{2} \mathrm{UR}\right)$ peel & $11.22 \pm 1.77$ & $1.55 \pm 0.07$ \\
\hline & & Fruit $\left({ }^{3} \mathrm{R}\right)$ peel & $15.30 \pm 3.06$ & $7.42 \pm 0.62$ \\
\hline 4. & P. amarus & Stem & $15.30 \pm 1.77$ & $2.42 \pm 0.18$ \\
\hline \multirow[t]{3}{*}{5.} & \multirow[t]{3}{*}{ B. diffusa } & Stem & $13.20 \pm 1.77$ & $2.10 \pm 0.22$ \\
\hline & & Leaf & $14.28 \pm 3.53$ & $4.60 \pm 0.48$ \\
\hline & & Root & $16.75 \pm 1.72$ & $1.36 \pm 0.10$ \\
\hline \multirow[t]{3}{*}{6.} & \multirow[t]{3}{*}{ T. belerica } & Leaf & $16.37 \pm 4.00$ & $6.09 \pm 0.32$ \\
\hline & & Stem & $23.12 \pm 4.71$ & $2.91 \pm 0.24$ \\
\hline & & Bark & $13.60 \pm 2.36$ & $3.15 \pm 0.60$ \\
\hline
\end{tabular}

Values are mean \pm SD of three replications; ${ }^{1} \mathrm{FW}$ : Fresh weight; ${ }^{2} \mathrm{UN}$ : Unripe; ${ }^{3} \mathrm{R}$ : Ripe 
Longa (CL) ripe rhizome. Epidemiological studies have shown that a high intake of carotenoid-rich diet is associated with decreased incidence of cancers, cardiovascular diseases, age-related muscular degeneration and cataract formation. The protective role of carotenoids in the body is to diminish the degradation of antioxidant enzymes due to deactivation of singlet oxygen [1]. The ability of carotenoids to quench singlet oxygen is related to its conjugated double bond system, and maximum protection is given by those having nine or more double bonds [17].

\subsubsection{Total Phenolic Content}

Experimental data demonstrate that the TPCs are widely distributed in different medicinal plants as well as their parts. The TPC in the tested medicinal plants ranged between 1.21 to $135.56 \mathrm{mg}$ of $\mathrm{GAE} / \mathrm{g}$, which has been summarized in Table 3. Considering this wide variation in the TPC, the plant samples were divided into three groups namely, high $(>40 \mathrm{mg})$, medium $(10-40 \mathrm{mg})$ and low $(<10 \mathrm{mg}) \mathrm{TPC} / \mathrm{g}$ of
GAE. Results showed that Terminalia belerica (TB) leaf had highest value of TPC followed by PA leaves and stem whereas moderate values of TPC were present in AP leaves and stem, B. diffusa (BD) leaves, TB stem, EP leaves. The lowest values of TPC were present in MP fruit unripe pulp. From our experimental results, it is evident that plants having higher concentrations of phenolics showed better antioxidant properties in comparison to the plants having lower concentrations of TPC. Production of phenolics and other phytochemicals are dependent on developmental stage, agroclimatic conditions and seasonal variations. TPC possess important biological properties like anti-carcinogenic, antimutagenic, anti-allergenic, anti-aging etc. and also they are known to defuse the toxic free oxygen radicals due to their antioxidant properties [18].

\subsubsection{Protein Content}

The experimental data showed wide variation of protein content in different tested medicinal plants (Table 3). Protein

Table 3. TPC, Protein and Carbohydrate Content in Different Plant Samples

\begin{tabular}{|c|c|c|c|c|c|}
\hline S.No. & Plant sample & Plant Parts & ${ }^{1} \mathrm{TPC}\left(\mathrm{mg} / \mathrm{g}\right.$ of ${ }^{2} \mathrm{GAE}$ of $\left.{ }^{3} \mathrm{DW}\right)$ & Protein (mg/g of $\left.{ }^{3} \mathrm{DW}\right)$ & $\begin{array}{c}\text { Carbohydrate (mg/g of } \\
\left.{ }^{3} \mathrm{DW}\right)\end{array}$ \\
\hline \multirow[t]{2}{*}{1.} & \multirow[t]{2}{*}{ A. peniculata } & Leaf & $30.70 \pm 2.62$ & $115.57 \pm 5.80$ & $39.07 \pm 3.98$ \\
\hline & & Stem & $21.14 \pm 0.94$ & $95.00 \pm 2.00$ & $30.60 \pm 10.20$ \\
\hline 2. & A. vera & Leaf & $8.68 \pm 0.82$ & $153.33 \pm 11.55$ & $47.04 \pm 5.82$ \\
\hline \multirow[t]{7}{*}{3.} & \multirow[t]{7}{*}{ M. paradisca } & Leaf & $15.54 \pm 0.39$ & $156.70 \pm 9.28$ & $82.75 \pm 6.89$ \\
\hline & & Flower & $6.63 \pm 0.16$ & $363.70 \pm 8.85$ & $32.16 \pm 3.98$ \\
\hline & & Fruit $\left({ }^{4} U R\right)$ pulp & $1.21 \pm 0.24$ & $30.00 \pm 1.73$ & $286.67 \pm 15.27$ \\
\hline & & Fruit $\left({ }^{5} \mathrm{R}\right)$ pulp & $2.17 \pm 0.25$ & $37.33 \pm 1.52$ & $505.00 \pm 5.00$ \\
\hline & & Fruit $\left({ }^{4} U R\right)$ peel & $3.82 \pm 0.59$ & $129.00 \pm 7.55$ & $130.00 \pm 10.00$ \\
\hline & & Fruit $\left({ }^{5} \mathrm{R}\right)$ peel & $11.45 \pm 0.61$ & $261.33 \pm 8.08$ & $266.67 \pm 5.77$ \\
\hline & & Flower spathe & $6.52 \pm 0.61$ & $251.00 \pm 6.24$ & $56.67 \pm 11.55$ \\
\hline \multirow[t]{2}{*}{4.} & \multirow[t]{2}{*}{ P. amarus } & Leaf & $81.72 \pm 4.29$ & $197.37 \pm 6.49$ & $63.33 \pm 5.77$ \\
\hline & & Stem & $49.09 \pm 2.24$ & $94.33 \pm 3.79$ & $33.33 \pm 5.77$ \\
\hline \multirow[t]{3}{*}{5.} & \multirow[t]{3}{*}{ B. diffusa } & Stem & $13.24 \pm 1.95$ & $139.33 \pm 3.05$ & $80.00 \pm 10.00$ \\
\hline & & Leaf & $21.10 \pm 0.64$ & $181.50 \pm 5.51$ & $43.33 \pm 5.77$ \\
\hline & & Root & $7.02 \pm 0.87$ & $122.97 \pm 6.27$ & $56.67 \pm 5.77$ \\
\hline \multirow[t]{3}{*}{6.} & \multirow[t]{3}{*}{ T. belerica } & Leaf & $135.56 \pm 7.38$ & $213.15 \pm 2.70$ & $52.87 \pm 3.98$ \\
\hline & & Stem & $38.38 \pm 4.11$ & $44.33 \pm 2.51$ & $34.67 \pm 4.62$ \\
\hline & & Bark & $18.08 \pm 2.76$ & $52.33 \pm 4.04$ & $43.33 \pm 4.62$ \\
\hline \multirow[t]{3}{*}{7.} & \multirow[t]{3}{*}{ C. longa } & Leaf & $13.50 \pm 0.28$ & $158.56 \pm 1.80$ & $29.88 \pm 3.98$ \\
\hline & & Rhizome $\left({ }^{5} \mathrm{R}\right)$ & $13.31 \pm 0.25$ & $213.33 \pm 1.52$ & $42.67 \pm 4.62$ \\
\hline & & Rhizome ( $\left.{ }^{4} U R\right)$ & $10.55 \pm 2.03$ & $438.66 \pm 6.65$ & $53.33 \pm 4.62$ \\
\hline \multirow[t]{2}{*}{8.} & \multirow[t]{2}{*}{ E. prostrate } & Leaf & $26.60 \pm 1.08$ & $208.83 \pm 7.23$ & $32.18 \pm 7.96$ \\
\hline & & Stem & $7.90 \pm 0.05$ & $75.66 \pm 1.52$ & $76.67 \pm 5.77$ \\
\hline
\end{tabular}

Values are mean \pm SD of three replications; ${ }^{1} \mathrm{TPC}$ : Total phenolic content; ${ }^{2} \mathrm{GAE}$ : Gallic acid equivalent; ${ }^{3} \mathrm{DW}$ : Dry weight; ${ }^{4} \mathrm{UN}$ : Unripe; ${ }^{5} \mathrm{R}:$ Ripe 
contents of plant samples ranged from $30.00 \mathrm{mg} / \mathrm{g}$ to 438.66 $\mathrm{mg} / \mathrm{g}$ of DW. The highest value of protein was present in $C$. longa unripe rhizome whereas moderate value of protein were shown in Aleo vera (AV) leaf, MP leaf and unripe peel, PA leaf, BD stem, leaf and root, CL leaf. The lowest value of protein content was present in MP unripe pulp. It has been shown that proteins have excellent potential as antioxidant additives in foods because they can inhibit lipid peroxidation through multiple pathways including inactivation of reactive oxygen species, scavenging free radicals and chelation of pro-oxidative transition metals [19]. Bhattacharjee et al. [20] demonstrated that the protein fraction of $P$. niruri protected liver damage caused by chemically induced oxidative stress in mice and hypothesized that it was probably due to increasing antioxidative defence. Annapoorani et al. [21] also reported that the plant protein fraction of various plants have hepatoprotective activity against carbon tetrachloride induced free radical toxicity in Swiss albino male mice.

\subsubsection{Carbohydrate Content}

The carbohydrate content in different parts of plants ranged between $29.88 \mathrm{mg} / \mathrm{g}$ to $505.00 \mathrm{mg} / \mathrm{g}$ of DW (Table 3). The highest carbohydrate content was observed in $M$. paradisca ripe fruit pulp as $505 \mathrm{mg} / \mathrm{g}$ of DW followed by MP unripe fruit pulp and ripe fruit peel. The lowest value of carbohydrate was present in CL leaves i.e. $29.88 \mathrm{mg} / \mathrm{g}$ of DW. Zhang et al. [22] showed that the sulfated polysaccharide fraction from Porphyra haltanesis, an important alga in China, has antioxidant activity, and a strong scavenging effect for superoxide radical and it inhibits lipid peroxidation. In another study, Kodali \& Sen [23] reported that the poly- saccharide isolated from probiotic bacteria had antioxidant and free radical scavenging activities. It has also been found that consumption of complex carbohydrates in combination with different antioxidant micronutrients may enhance the antioxidant defenses and improve lipid metabolism [1].

\subsection{Antioxidant Activity}

Those plant parts with a higher concentration of bioactive phytochemicals mainly total phenolics were examined for their antioxidant activity using ethanolic plant extracts (Tables 4 and 5). The antioxidant activities of the plant extracts have been attributed to various potential reasons, such as prevention of chain initiation, binding of transition metal ion catalyst, decomposition of peroxide, prevention of continued hydrogen abstraction, reducing ability, etc.

\subsubsection{Total Phenolic Content}

The tested ethanolic plant extracts showed wide variation of TPC from 19.38 (CL unripe rhizome) to $221.87 \mathrm{mg} / \mathrm{g}$ of GAE (TB leaf). TPCs of the selected plant parts of ethanolic extracts were observed in the order: TB leaf $>\mathrm{PA}$ leaf $>\mathrm{PA}$ stem $>$ TB stem $>$ AP leaf $>$ EP leaf $>$ AP stem $>C$ CL leaf $>$ BD leaf $>$ TB bark $>$ MP leaf $>$ CL ripe rhizome $>$ CL unripe rhizome. In a similar study, the total phenolic content of $C$. longa and E. prostrata were reported as $15.33 \mathrm{mg}$ of GAE/g [24-26] which had lower values compared to our results. But in another study the total phenolics in C. longa was reported as $67.9 \mathrm{mg}$ of GAE/100g [27] and $1.22 \mathrm{mg}$ of GAE/100g [28], much lower than our values. Rafat et al. [29] reported the total phenolics in A. peniculata leaves and stem as 75.86 and $55.02 \mathrm{mg}$ of GAE/g, respectively, the values were higher

Table 4. Total Phenolic Content and Free Radical Scavenging Activity (in Term of $\mathrm{IC}_{50}$, $\mathrm{EC}_{50}$ and ARP) of Ethanolic Extracts of Selected Medicinal Plant Parts

\begin{tabular}{|c|c|c|c|c|c|c|}
\hline S.No. & Plant Sample & Plant Parts & $\begin{array}{c}{ }^{1} \mathrm{TPC}(\mathrm{mg} / \mathrm{g} \text { of } \\
\left.{ }^{2} \mathrm{GAE} \text { of }{ }^{3} \mathrm{EEP}\right)\end{array}$ & ${ }^{4} \mathbf{I C}_{50}$ & ${ }^{5} \mathbf{E C}_{50}$ & ${ }^{6} \mathrm{ARP}$ \\
\hline \multirow[t]{2}{*}{1.} & \multirow[t]{2}{*}{ A. peniculata } & Leaf & $52.37 \pm 1.34$ & $2.42 \pm 0.34$ & $105.21 \pm 15.04$ & $0.96 \pm 0.14$ \\
\hline & & Stem & $39.25 \pm 0.74$ & $7.34 \pm 0.57$ & $319.12 \pm 24.79$ & $0.31 \pm 0.02$ \\
\hline 2. & M. paradisca & Leaf & $27.80 \pm 0.99$ & $9.82 \pm 0.66$ & $426.95 \pm 28.73$ & $0.23 \pm 0.02$ \\
\hline 3. & P. amarus & Stem & $81.92 \pm 1.34$ & $1.20 \pm 0.23$ & $52.16 \pm 10.02$ & $1.95 \pm 0.34$ \\
\hline 4. & B. diffusa & Leaf & $33.94 \pm 0.22$ & $5.37 \pm 0.56$ & $233.62 \pm 24.43$ & $0.42 \pm 0.04$ \\
\hline \multirow[t]{2}{*}{5.} & \multirow[t]{2}{*}{ T. belerica } & Leaf & $221.87 \pm 4.75$ & $0.08 \pm 0.01$ & $3.61 \pm 0.66$ & $28.24 \pm 4.94$ \\
\hline & & Stem & $70.92 \pm 1.18$ & $1.91 \pm 0.22$ & $83.18 \pm 9.88$ & $1.21 \pm 0.15$ \\
\hline \multirow[t]{3}{*}{7} & \multirow[t]{3}{*}{ C. longa } & Leaf & $35.98 \pm 0.81$ & $4.79 \pm 0.58$ & $208.40 \pm 25.22$ & $0.48 \pm 0.06$ \\
\hline & & Rhizome $\left({ }^{7} \mathrm{R}\right)$ & $27.42 \pm 0.69$ & $11.71 \pm 0.58$ & $510.72 \pm 25.59$ & $0.19 \pm 0.01$ \\
\hline & & Rhizome $\left({ }^{8} \mathrm{UR}\right)$ & $19.38 \pm 1.73$ & $9.86 \pm 0.77$ & $428.69 \pm 33.61$ & $0.25 \pm 0.02$ \\
\hline 8. & Quercetin & Standard & -------- & $0.04 \pm 0.01$ & $1.51 \pm 0.05$ & $65.96 \pm 1.96$ \\
\hline
\end{tabular}

Values are mean \pm SD of three replications; ${ }^{1} \mathrm{TPC}$ : Total phenolic content; ${ }^{2} \mathrm{GAE}$ : Gallic acid equivalent; ${ }^{3} \mathrm{EEP}$ : Ethanolic extract powder; ${ }^{4} \mathrm{IC}$ : Inhibitory concentration; ${ }^{5} \mathrm{EC}$ : Efficiency concentration; ${ }^{6} \mathrm{ARP}$ : Anti radical power; ${ }^{7} \mathrm{R}$ : Ripe; ${ }^{8} \mathrm{UN}$ : Unripe 
Table 5. Superoxide Anion Scavenging Activity, Reducing Power, Lipid Peroxidation and Ferric Thiocyanate Assay Activity of Selected Plant Parts

\begin{tabular}{|c|c|c|c|c|c|c|}
\hline S.No. & Plant Sample & Plant Parts & ${ }^{1} \mathrm{SOD}\left(\mathrm{IC}_{50}\right)$ & ${ }^{2} \mathbf{R} \mathbf{P}$ & ${ }^{3} \mathrm{LPO}\left(\mathrm{IC}_{50}\right)$ & ${ }^{4}$ FTC $\left(\right.$ IC $\left._{50}\right)$ \\
\hline 1. & A. peniculata & Leaf & $12.45 \pm 1.20$ & $7.28 \pm 0.56$ & $10.34 \pm 0.42$ & $4.07 \pm 0.76$ \\
\hline 2. & M. paradisca & Leaf & $65.99 \pm 2.04$ & $14.62 \pm 0.51$ & $121.70 \pm 2.24$ & $17.88 \pm 0.65$ \\
\hline 3. & P. amarus & leaf & $7.73 \pm 0.74$ & $1.77 \pm 0.26$ & $6.06 \pm 0.88$ & $1.99 \pm 0.13$ \\
\hline 4. & B. diffusa & Leaf & $115.72 \pm 3.89$ & $13.06 \pm 1.07$ & $55.74 \pm 1.48$ & $30.78 \pm 1.11$ \\
\hline \multirow[t]{3}{*}{5.} & \multirow[t]{3}{*}{ T. belerica } & Leaf & $0.39 \pm 0.08$ & $0.27 \pm 0.02$ & $0.31 \pm 0.06$ & $0.89 \pm 0.08$ \\
\hline & & Stem & $2.58 \pm 0.35$ & $0.98 \pm 0.11$ & $1.60 \pm 0.41$ & $2.65 \pm 0.51$ \\
\hline & & Bark & $25.27 \pm 2.26$ & $1.42 \pm 0.30$ & $5.36 \pm 0.64$ & $0.48 \pm 0.07$ \\
\hline \multirow{2}{*}{7} & \multirow{2}{*}{ C. longa } & Rhizome $\left(\mathrm{R}^{5}\right)$ & $17.68 \pm 1.40$ & $27.08 \pm 0.90$ & $6.57 \pm 0.49$ & $6.58 \pm 1.18$ \\
\hline & & Rhizome $\left(\mathrm{UR}^{6}\right)$ & $25.39 \pm 0.92$ & $16.46 \pm 0.62$ & $8.64 \pm 0.89$ & $14.92 \pm 1.57$ \\
\hline 8. & Quercetin & Standard & $2.33 \pm 0.05$ & $1.12 \pm 0.02$ & $0.007 \pm 0.001$ & $0.45 \pm 0.01$ \\
\hline
\end{tabular}

Values are mean \pm SD of three replications; ${ }^{1}$ SOD: Super oxide anion scavenging activity; ${ }^{2}$ RP: Reducing power; ${ }^{3}$ LPO: Lipid peroxidation; ${ }^{4}$ FTC: Ferric thiocyanate assay activity; ${ }^{5} \mathrm{R}$ : Ripe; ${ }^{6} \mathrm{UR}$ : Unripe

than those observed in our study. These variations may be attributed to the agro-climatic conditions and seasonal variations. Typical phenolics that possess antioxidant activity have been characterized as phenolic acid and flavonoids. Due to their useful antioxidant activity, phenolics have repeatedly been implicated as natural antioxidants in fruit, vegetable and other medicinal plants.

\subsubsection{Free Radical Scavenging Activity (FRSA)}

The determination of FRSA value by DPPH is an easy, rapid and sensitive method to determine the antioxidant potential of a specific compound or plant extracts. The phytochemicals present in the plant extract, react with the DPPH radicals and are converted into a colourless $\alpha$ - $\alpha$-diphenyl- $\beta$ picryl hydrazine. The decrease in the absorbance observed is due to reduction of the DPPH* radical by antioxidants present in the plant extracts, which form stable DPPH-H. The FRSA values of the plants samples have been summarized in Table 4. Results were expressed in the terms of inhibitory concentration $\left(\mathrm{IC}_{50}\right)$, efficiency concentration $\left(\mathrm{EC}_{50}\right)$ and anti-radical power (ARP). Lower value of $\mathrm{IC}_{50}$ and $\mathrm{EC}_{50}$ showed higher antioxidant capacity. ARP was determined as the reciprocal value of the $\mathrm{IC}_{50}$ and $\mathrm{EC}_{50}$, representing a comparable term for the effectiveness of antioxidant and radical scavenging capacity. The larger the ARP, the more efficient is antioxidant capacity. The FRSA in terms of inhibitory concentration $\left(\mathrm{IC}_{50}\right)$ ranged from 0.08 (TB leaf) to $11.74 \mathrm{mg} / \mathrm{ml}$ (CL ripe rhizome) whereas $\mathrm{EC}_{50}$ ranged from 3.61 (TB leaf) to $510.72 \mathrm{mg} / \mathrm{mg}_{\mathrm{DPPH}}$ (CL ripe rhizome). The ARP ranged between 28.24 (TB Leaf) to 0.19 (CL unripe rhizome). Table 4 showed that TB leaf has better free radical scavenging capacity when it was compared with other plant extracts and is similar to the standard. The parameter $\mathrm{EC}_{50}$ is also a direct quantitative measure for antioxidant activity. High antioxidant activity is characterized by low $\mathrm{EC}_{50}$ value and vice versa. It has been found that the free radicals are involved in the genesis of many diseases. So the herbal drugs containing free radical scavengers such as phenolics, ascorbic acid, flavonoids, carotenoids etc. may be useful in the treatment of many diseases.

\subsubsection{Superoxide Anion Radical Scavenging Activity}

Superoxide anion is a well recognized free radical species that is generated continuously by auto-oxidation process or by several cellular processes including the microsomal and mitochondrial electron transport systems. Moreover, superoxide anions produce other kinds of cell damaging free radicals and oxidizing agents that initiate DNA damage, protein oxidation and lipid peroxidation. The PMS-NADH-NBT system was used to determine superoxide anion radical scavenging activity which is a well known non enzymatic universal method. Table 5 shows that ethanolic T. belerica leaf extract showed maximum NBT reduction whereas ethanolic extract of $B$. diffusa leaf showed minimum NBT reduction or high inhibitory concentration. The superoxide anion radical scavenging activity of the thirteen plant parts examined appeared to be in the following order: TB leaf $>$ TB stem $>$ PA leaf $>$ AP leaf $>$ CL leaf $>$ CL ripe rhizome $>$ PA stem $>$ EP leaf $>$ TB bark $>$ CL unripe rhizome $>$ AP stem $>$ MP leaf $>$ BD leaf.

\subsubsection{Reducing Power}

From the experimental results, it was found that the ethanolic extract of different plant samples had remarkable po- 
tential to reduce the ferric ion into ferrous ion which is also a parameter to measure the antioxidant activity. The reducing power of extracts was reported in terms of ASE $/ \mathrm{ml}$. The ethanolic leaf extract of $T$. belerica exhibited potent scavenging activity against ferric ion $(0.27 \mathrm{ASE} / \mathrm{ml})$ in a concentration dependent manner whereas ripe rhizome of $C$. longa had lowest value of reducing power (27.08). The reducing power of other plant extracts appeared to be in the following order: TB leaf $>$ TB stem $>$ TB bark $>$ PA leaf $>$ PA stem $>$ EP leaf $>$ CL leaf $>$ AP leaf $>$ AP stem $>$ BD leaf $>$ MP leaf $>$ CL unripe rhizome $>\mathrm{CL}$ ripe rhizome. The ASE value is inversely proportional to reducing power [2]. A concentration dependent increase in absorbance and phenolic content implies that there is a direct relationship of the concentration of total phenolics with the reducing power. In the reducing power assay, presence of antioxidant in the sample results in reduction of ferric ion to ferrous ion by donating an electron. The amount of ferrous complex can then be monitored by measuring the colour intensity of Perls' Prussion Blue formation. Increase in absorbance at $700 \mathrm{~nm}$ indicates an increase in the reductive ability of the plant extract. The extract that exhibits a good reducing power can act as electron donor or may terminate the free radical chain reaction.

\subsubsection{Lipid Peroxidation Assay}

The present study was carried out to determine the inhibition of lipid peroxidation by the plant extracts in presence of ferrous ion under in vitro conditions and was expressed in terms of $\mathrm{IC}_{50}$ (Table 5). Lipid peroxidation is the result of any free radical attack on membrane or lipid rich constituents present in the system which may be enzymatic (Fe/NADPH) or non-enzymatic (Fe/ascorbic acid). Here we used egg homogenate as lipid rich medium to assay free radical mediated lipid peroxidation, which is a non-enzymatic method. The extracts showed varying levels of lipid peroxidation inhibition and the inhibitory concentrations varied from 0.31 to $121.70 \mathrm{mg} / \mathrm{ml}$ of plant extract. Among the tested plants samples, the ethanolic $T$. belerica leaf extracts showed lowest inhibitory concentration $(0.31 \mathrm{mg} / \mathrm{ml})$ while $M$. paradisca leaf had highest inhibitory concentration $(121.70 \mathrm{mg} / \mathrm{ml})$. The anti-lipid peroxidation properties of plant extracts were found in the order: TB leaf $>$ TB stem $>$ CL leaf $>$ TB bark $>$ $\mathrm{PA}$ leaf $>\mathrm{CL}$ ripe rhizome $>\mathrm{CL}$ unripe rhizome $>\mathrm{AP}$ leaf $>\mathrm{EP}$ leaf $>$ AP stem $>$ BD leaf $>$ PA stem $>$ MP leaf. The high anti lipid peroxidation activity of plant extracts may be attributed to the higher concentration of antioxidant compounds present in plants which inhibit lipid peroxidation either by the chelation of ferric ion or by trapping free radicals. During lipid peroxidation in biological systems, oxidative degradation of polyunsaturated fatty acids, a number low molecularweight end products such as malonaldehyde (MDA) are generated which react with two molecules of thiobarbituric acid to give a pinkish red chromagen [30]. The inhibitory effect of ethanolic $T$. belerica leaf extract against thiobarbituric acid reactive substance (TBARS) formation was significantly higher than that of other plants extract and our results also showed that the inhibitory effect of TB leaf on TBARS formation was in dose dependent manner.

\subsubsection{Ferric Thiocyanate Assay (FTC)}

Membrane lipids such as linoleic and arachidonic acids are the primary targets of lipid peroxidation by the free radi- cals. The FTC method is used to measure the amount of peroxide produced during the initial stages of lipid oxidation, whereas TBA method is used to measure a later stage of lipid peroxidation. Ferric ions are formed with reaction of peroxide with ferrous chloride. The ferric ions then unite with ammonium thiocyanate producing a red-coloured substance, ferric thiocyanate. Maximum FTC activity was observed in T. belerica bark $(0.48 \mathrm{mg} / \mathrm{ml})$ and minimum in BD leaf $(30.78 \mathrm{mg} / \mathrm{ml})$. Based on the $\mathrm{IC}_{50}$ value, the order of FTC activity of different extracts was found to be: TB bark> TB leaf $>$ PA leaf $>$ TB stem $>$ AP leaf $>$ CL ripe rhizome $>$ AP stem $>$ EP leaf $>$ CL leaf $>$ PA stem $>$ CL unripe rhizome $>$ MP leaf $>$ BD leaf.

\section{CONCLUSION}

We demonstrate for the first time that the ethanolic leaf extracts of T. belerica and P. amarus exhibited strong and effective in vitro antioxidant activity by chelation to metal ions as well as scavenging free radicals. Presence of poly phenolics in the both extracts is mainly responsible for their overall antioxidant activity. So, it can be stated that ethanolic leaf extracts of T. belerica and P. amarus may be good and easily accessible source of nutraceutical compounds. Terminalia belerica, an ingredient of Indian Ayurvedic drug 'triphala' is used for the treatment of digestion and liver disorders. Indian Ayurvedic literature had also shown reduction in the levels of lipids in hypercholesterolemic animals and possession of antihepatotoxicity, anti-HIV-1, antimalarial, antimutagenic and antifungal activities. Phyllanthus amarus has been used in Ayurvedic medicine for over 2,000 years and has a wide number of traditional uses: employing the whole plant for jaundice, gonorrhea, frequent menstruation, diabetes, skin ulcers, sores, swelling, and itchiness. It is a very effective for liver remedy and is also used for clearing gall and bladder stones. We consider that both extracts deserve more intensive study including their in vivo antioxidant activity, bioavailability and possible protection against cardiovascular diseases to understand their inherent potentials as nutraceuticals.

\section{LIST OF ABBREVIATIONS}

$\begin{array}{lll}\mathrm{ARP} & = & \text { Anti radical power } \\ \mathrm{EC} & = & \text { Efficiency concentration } \\ \mathrm{EEP} & = & \text { Ethanolic extract powder } \\ \mathrm{FRs} & = & \text { Free radicals } \\ \mathrm{FTC} & = & \text { Ferric thiocyanate assay activity } \\ \mathrm{GAE} & = & \text { Gallic acid equivalent } \\ \mathrm{IC} & = & \text { Inhibitory concentration } \\ \mathrm{LPO} & = & \text { Lipid peroxidation } \\ \mathrm{R} & = & \text { Ripe } \\ \mathrm{ROS} & = & \text { reactive oxygen species } \\ \mathrm{RP} & = & \text { Reducing power } \\ \mathrm{TPC} & = & \text { Total phenolic content } \\ \mathrm{UR} & = & \text { Unripe }\end{array}$




\section{CONFLICT OF INTEREST}

The authors confirm that this article content has no conflicts of interest.

\section{ACKNOWLEDGEMENTS}

PS, US and MS are grateful to University Grants Commission, New Delhi for the award of Junior Research Fellowship under "Research Fellowship in Science for Meritorious Students (RFSMS)"scheme. SPV is thankful to UPCST, Lucknow for providing SRF.

\section{REFERENCES}

[1] Singh P, Singh U, Shukla M, Singh RL. Antioxidant activity imparting biomolecules in Cassia fistula. Adv Life Sci 2008a; 2(1\&2): 23-8.

[2] Singh BN, Singh BR, Singh RL, et al. Polyphenolics from various extracts/fractions of red onion (Allium cepa) peel with potent antioxidant and antimutagenic activities. Food Chem Toxicol 2009a; 47: 1161-67.

[3] Izunya AM, Nwaopara AO, Aigbiremolen A, et al. Morphological and biochemical effects of crude aqueous extract of mangifera indica 1. (mango) stem bark on the liver in wistar rats. Res J Appl Sci Eng Technol 2010; 2(5): 460-5.

[4] Singh BN, Singh BR, Singh RL, Prakash D, Sarma BK, Singh HB. Antioxidant and anti-quorum sensing activity of green pod of Acacia nilotica L. Food Chem Toxicol 2009b; 47: 778-86.

[5] AOAC. Official method of analysis, Association of official analytical chemists, $14^{\text {th }}$ ed. Arlington Virginia: AOAC 1984; pp. 292343.

[6] Jensen A. Chlorophylls and physiological method: physiological and biochemical method. In: Hellebust JA, Craigie JS, Eds, Cambridge: Cambridge University Press 1978; pp. 5-7.

[7] Ragazzi E, Veronese G. Quantitative analysis of phenolic compounds after thin layer chromatographic separation. J Chromatogr 1973; 77: 369-75.

[8] Lowry OH, Rosebrough NJ, Farr AL, Randall RJ. Protein measurement with the Folin phenol reagent. J Biol Chem 1951; 193: 265-75.

[9] Thomas G, Ludwig Hyman JVG. The anthrone method for the determination of carbohydrates in foods and in oral ringing. J Dent Res 1956; 35(1): 109-16.

[10] Yen GC, Duh PD. Scavenging effect of methanolic extracts of peanut hulls on free radical and active oxygen. J Agric Food Chem 1994; 42: 629-32.

[11] Nishikimi M, Rao NA, Yagi K. The occurrence of superoxide anion in the reaction of reduced phenazine methosulphate and molecular oxygen. Biochem Biophys Res Commun 1972; 46: 849-64.

[12] Apati P, Szentmihalyi K, Kristo ST, et al. Herbal remedies of Solidago-correlation of phytochemical characteristics and antioxidative properties. J Pharm Biomed Anal 2003; 32: 1045-53.
[13] Ohkawa M, Ohisi N, Yagi K. Assay for lipid peroxides in animal tissues by thiobarbituric acid reaction. Anal Biochem 1979; 95: 351-8.

[14] Tsuda T, Watanabe M, Ohshima K, Yamamoto A, Kawakishi S, Osawa T. Antioxidative components isolated from the seed of tamarind (Tamarindus indica L.). J Agric Food Chem 1994; 42: 2671-4.

[15] Stephen SL, Deborah C, Min D, Val V, Vincet C, Xianglin S. Antioxidant properties of fruit and vegetable juices: More to the story than ascorbic acid. Ann Clin Lab Sci 2002; 32: 193-200.

[16] Cioroi M. Study on L-ascorbic acid contents from exotic fruits. Cercetari Agronomice Moldova 2007; 1(129): 23-7.

[17] Foote CS, Chang YC, Denny RW. Chemistry of singlet oxygen X. Carotenoid quenching parallels biological protection. J Am Chem Soc 1970; 92: 5216-8.

[18] Dhakarey R, Upadhyay G, Singh BN, et al. Phenolic contents and antioxidant potential of Rhododendron species. Ind J Agric Biochem 2005; 18(1): 40-3.

[19] Singh U, Singh P, Shukla M, Kakkar P, Singh RL. Antioxidant activities of vegetables belonging to papilionaceae family. Adv Life Sci 2008b; 2(1\&2): 31-6.

[20] Bhattacharjee R, Sil PC. The protein fraction of Phyllanthus niruri plays a protective role against acetaminophen induced hepatic disorder via its antioxidant properties. Phytother Res 2006; 20(7): 595-601.

[21] Annapoorani S, Sheereen NH, Hema R. Hepatoprotective effects of protein fractions of selected medicinal plants against $\mathrm{CCl} 4$ induced mice. J Ecotoxicol Environ Monit 2006; 16(1): 83-90.

[22] Zhang Q, Yu P, Li Z, Zhang H, Xu Z, Li P. Antioxidant activities of sulfated polysaccharide fractions from Porphyra haitanesis. J Appl Phycol 2003; 15(4): 305-10.

[23] Kodali VP, Sen R. Antioxidant and free radical scavenging activities of an exopolysaccharide from a probiotic bacterium. Biotechnol J 2008; 3(2): 245-51.

[24] Gan RY, Xu XR, Song FL, Kuang L, Li HB. Antioxidant activity and total phenolic content of medicinally plants associated with prevention and treatment of cardiovascular and cerebro-vascular diseases. J Med Plant Res 2010; 4(22): 2438-44.

[25] Johnson CE, Oladeinde FO, Kinyua AM, et al. Comparative assessment of total phenolic content in selected medicinal plants. Niger J Nat Prod Med 2008; 12: 40.

[26] Rao DB, Kiran CR, Madhavi Y, Rao PK, Rao TR. Evaluation of antioxidant potential of Clitoria ternata L. and Eclipta prostrate L. Ind J Biochem Biophys 2009; 46: 247-52.

[27] Maizura M, Aminah A, Wan Aida WM. Total phenolic content and antioxidant activity of kesum (Polygonum minus), ginger (Zingiber officinale) and turmeric (Curcuma longa) extract. Int Food Res J 2011; 18: 526-31.

[28] Mongkolsilp S, Pongbupakit I, Lee N, Sitthithaworn S. Radical scavenging activity and total phenolic content of medicinal plant used in primary health care. SWU J Pharm Sci 2004; 9(1): 32-5.

[29] Rafat A, Philip K, Muniandy S. Antioxidant potential and content of phenolic compound in ethanolic extracts of selected parts of Andrographis peniculata. J Med Plant Res 2010; 4(3): 197-202.

[30] Walia H, Kumar H, Aroa S. Analysis of antioxidant activity of methanol extract/fraction of Termenalia chebula Retz. J Chin Clin Med 2007; 7(2): 1

\footnotetext{
Received: August 17, 2012

Revised: August 22, 2012

Accepted: August 24, 2012

(C) Singh et al.; Licensee Bentham Open.

This is an open access article licensed under the terms of the Creative Commons Attribution Non-Commercial License (http://creativecommons.org/licenses/by-nc/3.0/) which permits unrestricted, non-commercial use, distribution and reproduction in any medium, provided the work is properly cited.
} 